\title{
РОБЕРТ БРАУНИНГ И НЕГОВИТЕ ДРАМСКИ МОНОЛОЗИ - - МОСТ ПОМЕЃУ ЕКСПЕРИМЕНТОТ И ТРАДИЦИЈАТА
}

\author{
Милан Дамјаноски \\ Универзитет „Св. Кирил и Методиј“, Скопје \\ m.damjanoski@flf.ukim.edu.mk
}

Во нашиот труд ќе дадеме кус приказ на историскиот развој на драмскиот монолог како хибриден жанр меѓу поезијата и драмата, за чиј развој најмногу е заслужен Роберт Браунинг. Неговиот развој доаѓ како директна последица на кризата на поезијата да се справи со предизвиците што произлегоа од огромните промени на сите полиња во XIX век. Притоа, ќе дадеме приказ на главните структурни и тематски одлики, како и на важноста на драмската персона како главен наратор и нејзината улога во пробивањето на повеќегласноста во монолошката структура на поезијата. Конечно, ќе се осврнеме на драмскиот монолог како жанр што му дава можност на Браунинг да ги имитира и да ги инкорпорира најразличните гласови и дискурси во британското општество. Како пример за оваа постапка посебно ќе се осврнеме на Вийезой Роланя йреg Мрачнайа Кула, преку кој ќе се обидеме да ја прикажеме поетиката и наративните стратегии на Браунинг во жанрот на драмскиот монолог.

Клучни зборови: Роберт Браунинг, поезија, викторијанска книжевност, драмски монолог, драмска персона 


\title{
ROBERT BROWNING AND HIS DRAMATIC MONOLOGUES AS A BRIDGE BETWEEN EXPERIMENT AND TRADITION
}

\author{
Milan Damjanoski \\ Ss. Cyril and Methoduis University, Skopje \\ m.damjanoski@flf.ukim.edu.mk
}

In our paper we shall give a short overview of the historical development of the dramatic monologue, a hybrid genre between poetry and drama in which Robert Browning played a crucial role to develop. It resulted directly from the crisis of poetry and its inability to deal with the challenges caused by the tectonic changes in all areas of 19th century society. We shall discuss the main structural and thematic features of the dramatic monologue, as well as the importance of the dramatis personae as the narrator and its role in incorporating polyphony in the monological structure of poetry. Finally, we shall also look at the dramatic monologue as a genre providing Browning the platform to imitate and incorporate the myriad voices and discourses present in British society. As a specific example for this approach, we shall analyze the dramatic monologue Child Roland to the Dark Tower Came in order to more concretely present the poetics and narrative strategies of Browning.

Keywords: Robert Browning, poetry, Victorian literature, dramatic monologue, dramatis personae 


\section{1 Вовед}

Роберт Браунинг е претставник на викторијанскиот период, но тој е и поет кој не само што е производ на своето време и на викторијанското општество туку и на поширокото западно културно наследство, ставајќи го во уникатна позиција за да може да ги изрази сите различни аспекти на викторијанскиот период.

Во нашиот труд сакаме да дадеме кус приказ на пристапот и на постапките на Роберт Браунинг, во обидот преку поезијата да ги согледа, да стапи во дијалог и да се обиде да даде одговор на бројните дилеми со кои се соочува викторијанското општество на преминот меѓу две различни историски ери. Поради тоа, прво сакаме да дадеме преглед на најважните аспекти на поетската форма што ја користи најчесто во својот дијалог, а тоа е драмскиот монолог. Ке се задржиме на начинот на кој наративната структура на драмскиот монолог и фокусот на драмската персона како наратор овозможуваат влез и продуктивно содејство на важните општествени, идеолошки и религиозни дискурси во рамките на тематскиот спектар на дадената песна. За да го илустрираме подобро овој дискурзивен процес, ќе анализираме еден од

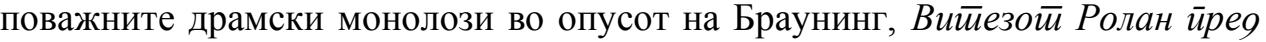
Мрачнай $а$ Кула. Тоа што го прави податливо ова дело за потребите на нашата анализа е неговиот статус на современа песна заснована на традиционални книжевни теми, ликови и наративни постапки, како што се романсата и епскиот дискурс, што го овозможува воведувањето на дискурсите на современото општество и на книжевноста кои ги проблематизираат и ги преиспитуваат можностите на традиционалните модели. Конечно, преку поединечна анализа на начинот на кој Браунинг ги структурира различните дискурси во рамките на семантичкиот универзум на драмскиот монолог, сакаме да укажеме на предизвиците со кои се соочувале поетите од викторијанскиот период за да најдат соодветна поетика за перципирање и претставување на новата општествена реалност на нивното време.

\section{2 Роберт Браунинг}

Животот и кариерата на Роберт Браунинг (1812-1889) го опфаќаат речиси целиот викторијански период. Тој ги објавува првите дела на почетокот на ерата, а најголемите признанија и слава како поет ги доживува на крајот од својот живот во 1880-тите. Тоа е период кога во подем е империјализмот, но и кога веќе почнува кризата на викторијанските вредности и почетокот на новите естетски и книжевни идеи, кои ќе доведат до појавата на модернизмот. Сето тоа го ставило Роберт Браунинг во уникатна позиција да може да ги изрази различните аспекти на викторијанскиот период. Тој е производ на своето време и на викторијанското општество, но и на поширокото западно културно наследство. 
Неговиот најзначаен придонес кон англиската поезија е развојот и популаризирањето на драмскиот монолог. Роберт Браунинг во своите драмски монолози опфаќа цело богатство ликови, периоди и настани од историјата, историски и книжевни собитија, црпејќи од својата широка и огромна ерудиција и од искуствата од патувањата и животот во Европа, а особено Италија, како и од богатата библиотека ${ }^{1}$ на татко му, која тој ќе ја збогатува целиот свој живот. Уште во младоста е изложен на „сите прогресивни, религиозни, политички и општествени идеи што владееја во средината на XIX век“ (Kennedy 2007: 47), како што се „законот за укинувањето на забраната за увоз на пченица, образовните реформи, женските права, слободата на религиозно определување, борбата против ропството и поддршката за работничката класа““ (ibid., 48). Подоцна, за време на престојот во Франција и во Италија со сопругата, поетесата Елизабет Барет Браунинг, тој е сведок на владеењето на Наполеон III и борбата за обединување на Италија, а воедно, има можност подобро да се запознае со ренесансната уметност, која е честа тема во неговата поезија. Сите тие искуства ќе придонесат тој да се развие во „најинтернационалниот англиски писател од викторијанската ера“ (Kennedy 2007: 49). Браунинг го опсервира викторијанското општество од повеќе перспективи - како негов дел, но и однадвор, како своевиден апатрид. Во тоа тој ја споделува судбината и перспективата на Џејмс Џојс, но за разлика од него, по смртта на сопругата тој се враќа во Велика Британија, каде што го добива заслуженото признание од критиката, а особено од британската јавност. Освен големата популарност на неговите изданија, особено на неговите драмски монолози, краен доказ за неговото прифаќање е формирање на Друштвата за читање и проучување на неговата поезија, во кои неговите гледишта се земени како своевидна филозофија што ги рефлектира и ги заштитува вредностите на викторијанското време и општество. Како што укажа еден критичар, „на викторијанците што чувствуваа внатрешен немир предизвикан од промените во нивниот општествен и интелектуален свет, песните на Браунинг им ја задоволуваа потребата за духовна поткрепа“" (Kennedy 2007: 55).

Дијалогичната природа на драмскиот монолог и извонредната миметичка способност на Браунинг да ги имитира и да ги инкорпорира најразличните гласови и дискурси, му овозможи да го пренесе општествениот дијалог во своите дела. Сепак, Браунинг не е радикален бунтовник против својата средина и време како Бајрон или Шели, туку напротив, тој во исто време ги одразува, но и ги преиспитува сите комплексности на еден историски период и општество што во исто време е традиционално, но и отворено кон новините кои ги носат технологијата и науката. Поврзаноста на драмскиот монолог со поетската и со драмската традиција, кои имаат длабоки корени во англиската книжевност, не му дозволува да биде радикален во експериментирањето, бидејќи во основа, тоа претставува обид на овие две книжевни форми да се приспособат на предизвикот што им го поставува релативно новиот и свеж

\footnotetext{
${ }^{1}$ Ричард Кенеди во својата биографија на Роберт Браунинг, дава еден занимлив и сеопфатен преглед на книгите од најразлични периоди, теми и области во библиотеката на татко му (Kennedy 2007: 10-12).
} 
жанр на романот. Ова двојство е содржано и во ставовите на Браунинг, кој во најголем дел експериментира на јазично и стилско рамниште, но во однос на тематските и идеолошките аспекти на неговата поезија, тој е на линија со одредени традиционални официјални идеологии, како што е христијанството. Новините и експериментите што ги воведе тој во поезијата ќе добијат признание од идните генерации модернистички поети, како Т. С. Елиот и Езра Паунд, но ќе наидат на неразбирање и одредено неприфаќање од неговото време. Спротивна е ситуацијата во однос на неговата идеологија: Браунинг се смета за типичен претставник на викторијанскиот светоглед и верувања, кои пак, ќе бидат оспорени и нападнати од следните генерации. Поради тоа, на неговата поезија и користењето на драмскиот монолог и драмската персона гледаме како на извонреден и амбициозен обид преку книжевноста да се одбранат и да се зачуваат традиционалните идеали и вредности преку интегрирање на новите гледишта, гласови и постапки.

\section{3 Драмските монолози на Браунинг}

Браунинг во своите драмски монолози ја следи линијата на користење на ликот, која се надоврзува на концептот на Китс за негативната способност (negative capability), која подразбира целосна објективност и губење на идентитетот на авторот на сметка на полнотијата на гласот на ликот и нарацијата на настаните. Во англиската книжевност таа традиција се протега сѐ до Чосер и до Шекспир, кого и Китс го издвојува како идеален автор, чиј глас никогаш не можеме да го слушнеме. Делото на авторската рака во драмските монолози се гледа на нивото на организација и поставувањето на гласовите во структурата и нарацијата на делото, во што Браунинг се истакнува со своето мајсторство. Тука би се надоврзале на Бахтин, дека раката на авторот не е водена само од неговата идеја, креативност и писателска вештина, туку од ограничувањата и правилата на жанрот во кој работи, како и од општествените услови и ситуацијата во која твори (Bahtin 1989). Ние тука ја гледаме и главната причина и мотивација, но и ограничувањата и пречките во пробивањето на новите гласови во рамките на книжевните дела, особено тие базирани на традиционалните форми, жанрови и теми.

Драмскиот монолог е хибридна форма што ги урива границите на двете форми од кои потекнува: лирската поезија и драмата со своите монолози и солилоквии. Нејзиниот развој, колку и да се чини изненаден и револуционерен за своето време, претставува логичен чекор, бидејќи ниедна нова форма или жанр не може да настане без комбинирање на постојните форми со новите гласови, технологии и медиуми или, пак, без комбинирање на доминантните со некои подзаборавени, но витални стари форми. Како што посочува Кенеди, со драмскиот монолог „се задоволуваше потреба што театарот во XIX век не беше веќе способен да ја задоволи. Во секој случај, има поврзаност меѓу слабеењето на појавата на свежи нови драмски дела во Англија во XIX век и развојот на новите вештини за пишување драмски песни“" (Kennedy 2007: 86). 
Формата и природата на драмскиот монолог ја наметнуваат оваа полиакцентност и повеќегласност во монолошката структура на песната. Монологот по својата природа налага и бара стабилност и доминантност на едно гледиште, кое и покрај фактот што може да опфаќа размисла или расправа за одредена тема или настан, која опфаќа повеќе страни или погледи, конечно донесува еден краен суд или носи во себе доминантен став низ кој се филтрирани сите други и на кој тие му се потчинети. Тоа е пристап што е карактеристичен за многу од традиционалните книжевни жанрови, како што се епот, лириката, одата, кои го утврдиле својот авторитет во минатото и го пренеле во историскиот момент во кој твори Браунинг. Но, тие поетски жанрови веќе не можат да одговорат на новите историско-општествени тенденции на XIX век, што е осведочено со неуспехот на романтичарската поезија со монолошкиот лирски субјект да се справи со повеќегласната и мултиплицираната општествена реалност. Токму затоа поезијата се врти кон друг книжевен жанр, на кој му е својствена повеќегласноста, а која е поблиску според својата еволуција со поезијата од романот, а тоа е драмата.

Првите ликови што се јавуваат во драмските монолози на Тенисон и Браунинг (Св. Симеон Сйолйник, љубовникой на Порфирија) во 1830-тите се ликови што се на границите на прифатливото, на нормалното и на нормираното. Тие се наоѓаат во состојба на подвоеност, во состојба на психичка дилема за која можеби не се свесни на површината, но нивниот монолог укажува дека тие се во конфликт со нормите на општеството и со неговите закони. Овој конфликт повлекува појава на повеќегласност во рамките на внатрешниот или интимниот монолог, што е својство на монологот во драмите и дозволува развој на повеќеслојност и комплексност во новиот жанр. Овие први монолози како да ги најавуваат можностите на новиот хибриден жанр на драмскиот монолог или на монодрамата, како што се опишува оваа нова форма на почетокот. Тој психолошки, но и општествен конфликт, укажува и на расцепот и на кревкоста на монолитноста и монологноста на традиционалните форми на поезијата и на драмата, како и на нивната неможност да се справат со новите појави во општеството, особено не во претходно утврдените и фиксирани форми и поджанрови.

Вообичаено, во анализите на драмските монолози на Браунинг, но и на самиот жанр, се потенцира психологијата на ликот и карактеристичната поставеност на монологот, кој помага да се скријат психолошките мотиви и да се открие целосниот психолошки профил на драмската персона. Една од функциите на драмската персона е преку својот глас да се претстави и да се обликува нарацијата, така што читателот зависи од неа за да ги осознае сите елементи на настанот или на приказната. Тоа ја трансформира драмската персона од дводимензионален лик, кој го одразува субјективниот карактер и улогата што ја има во наративното опкружување, во тродимензионален семантички простор, во кој се содржат сите елементи и структурата на нарацијата, при што преку неа се претставени и гласовите и постапките на другите ликови. Но, драмската персона во драмските монолози не доминира со точката на гледиште, бидејќ́ е лишена од привидната објективност и авторитетот на 
омнисцентниот наратор или, пак, на поетот како наратор. Драмската персона е свртена навнатре кон настаните, како директен учесник во нив, но и кон читателот како надворешен толкувач на значењето на песната. Дополнителна карактеристика на драмската персона е тоа што вообичаено таа е лоцирана во одреден минат историски период, за која е референт и преку која е семантички определена, но во исто време, преку неа современоста стапува во контакт и во дијалог со минатото, при што преку неа и нејзината реч се рефлектира современиот светоглед.

Во правилата и ограничувањата на поезијата, особено во фактот што Браунинг користи веќе зрело формирани и строги лирски и драмски форми, ја гледаме тешкотијата некогаш да се осознае вистинското значење и интенцијата на авторот. Но, од друга страна, мајсторството на Браунинг во версификацијата и во метриката, неговата богата ерудиција и лексика, како и неговата инвентивност и чувството за експериментирање, доведуваат до воспоставување рамнотежа, а во позначајните дела, како Мојайа ӣослеgна

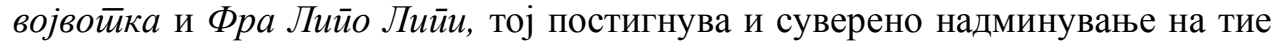
ограничувања. На ова треба да се додаде дека Браунинг намерно не сакал да го упрости својот творечки израз и да му олесни на читателот, бидејќи верувал дека песната е еден вид предизвик и процес низ кој треба да помине читателот за самиот да дојде до значењето. На тој начин читателот сам го засилува новиот глас на своето време и овозможува подобро да се чуе, да се материјализира и да се вклопи во новиот идентитет на општеството.

\section{4 Витезот Роланд пред Мрачната Кула}

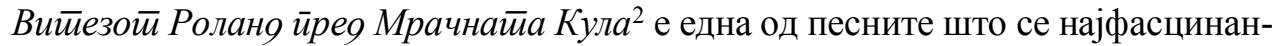
тни и најчесто подложни на различно толкување во опусот на Роберт Браунинг, што кажува многу за комплексноста и за опскурноста, но и за впечатливоста на нејзината содржина, стил и порака. На тоа се надоврзува и фактот што до крајот на животот Браунинг не сакал да даде дефинитивно објаснување на енигматичната приказна за младиот витез кој се наоѓ во потрага по Мрачната Кула. Многу критичари се осврнуваат на песната како на алегорија на психичката состојба на поетот во дадениот момент, за што песната дава богат материјал со мрачните и гротескните описи на пејзажот, која е алегорија рамна на моралниот и духовниот пустош на Пустиай $а$ земја на Т.С. Елиот, песна што се чини дека ја антиципира речиси седумдесет години претходно. Тоа е продукт на едно акумулирано животно и книжевно искуство, кое тлеело и зреело во потсвеста, кое го чека својот момент да избликне, слично како Кублај Кан на Колриџ или циклусот за Марко Крале на Конески. Токму оваа историја и заднина на нејзи-

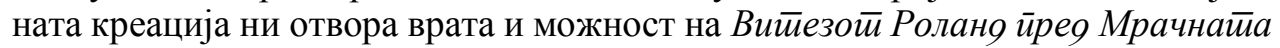

\footnotetext{
${ }^{2}$ Childe Harold to the Dark Tower Came. In Browning, Robert. (1994). The Poems of Robert Browning. Hertfordshire: Wordsworth Editions Limited. Понатаму во текстот преводот на сите извадоци од песната е дело на авторот.
} 
Кула да гледаме како на песна егземплар за тенденцијата на општествените процеси и појави да го чекаат вистинскиот момент да избликнат и да се искажат во рамките на веќе постојните и утврдени општествени и книжевни дискурси и рамки. Како што кажува Ричард Кенеди во својата биографија за Браунинг, тоа е песна што е родена во еден ден, чија инспирација му дошла на поетот несвесно и која барала да биде напишана веднаш и истиот ден. Раѓањето на песната доаѓ по периодот на непишување, кој траел три години, додека се грижел за здравјето на сопругата и кога тие биле сведоци на немирите и на револуционерните движења што ја зафатиле Европа, особено за време на нивниот престој во Франција и во Италија. Воедно, тоа е и период на големиот дијалог на идеите во европското и во британското општество, кој произлезе од големите научни, технолошки и културни иновации во XIX век. Таа го означува периодот на творештво што ќе кулминира со издавањето на неговата можеби најпозната и најзначајна збирка драмски монолози, Мажи и жени (1855) во кои се опфатени многу од главните теми во поетскиот опус на Роберт Браунинг.

Присуството на различни книжевни и општествени дискурси може да се согледа во структурата и во содржината на песната и начинот на кој Браунинг ги користи и ги применува книжевните форми што се дел од песната и очекувањата што ги носат тие со себе, т.е. нејзината семиосфера. Песната е заснована на жанрот романса, следејќи го добро познатиот мотив за витезот кому му е зададена задача и кој тргнува на пат во потрага и авантура за да ја оствари таа задача. Иако романсата е средновековен жанр, таа има оставено длабока трага во историјата на англиската книжевност и е интегрален дел од нејзината традиција, така што претставува дел од семиосферата како на Браунинг така и на неговиот читател современик. Тоа е потенцирано со фактот што романсата како жанр доживеа своја преродба во XIX век, како дел од тенденцијата на британското општество на вртење кон своето минато во обид да најде одговор на современите проблеми, особено во творештвото на Тенисон, Скот, а подоцна и на предрафаелитите. Притоа, таа носи и одредени очекувања кај читателот со својата форма и мотиви, каде што, без разлика дали е обработена во покуса лирска форма или подолга епска форма, авантурата на јунакот е прикажана или навестена во целина, од почетокот до крајот, без разлика дали е среќен или трагичен. Браунинг во формата на песната ги изневерува тие очекувања, затоа што читателот е соочен само со фрагмент од авантурата на младиот витез Роланд, т.е. со средишниот дел на неговиот пат. Ние не сме известени за почетокот на неговата авантура, како ни тоа која е институцијата или силата што му ја доделува мисијата, а песната завршува во моментот кога треба да ја изврши мисијата и да влезе во Мрачната Кула. Не знаеме ни што се крие во Мрачната Кула, ниту дали таму го чека непријател кој треба да го победи, или богатство, или личност што треба да ја спаси. Дискурсот на романсата и на средновековното витештво е организацискиот принцип на семиосферата на песната, кој Роберт Браунинг уште од почеток намерно го изневерува и на тој начин го отвора за преиспитување на целиот негов историски, културен и книжевен семантички потенцијал. Со тоа што современата 
песна користи само дел од стандардниот наратив и заплет на романсата, Браунинг ни сигнализира дека го става фокусот само на одреден спектар од нејзините семантички потенцијали, кои се од интерес за неговата современост. Тој го сопоставува дискурсот на романсата и на средновековието со современиот момент и неговите норми и вредности, т.е. го воведува во неговиот хоризонт на вредности. Тоа е првиот знак за читателот за модернизирање на средновековниот дискурс и дека имаме работа со оригинално современо дело, а не со епигонска стилизација.

Понатаму, за разлика од нарацијата во епот и романсата, песната е раскажана од драмска персона во прво лице еднина, наместо од поетот или од сезнаечкиот наратор, на тој начин воведувајќи ја романсата во романтичарскиот дискурс на лирскиот субјект, инкорпорирајќи го и него во семиосферата на песната. Епскиот дискурс, па дури и романтичарскиот дискурс, секогаш во себе ја носи претпоставката на обединетоста на гледиштето и нарацијата во еден субјект, т.е. поетот или главниот херој кој го одредува погледот на светот и кодот за неговата перцепција и толкување. Со нивното вклучување во семиосферата и во структурата на песната повторно се проблематизира нивниот легитимитет како организациски и моделативни општествени и книжевни принципи, што се вклопува во темата на алиенацијата, на изгубеноста и на немоќта на витезот Роланд во наративниот свет на песната. Тој е опкружен во својата потрага и мисија од гласови што го насочуваат или му ја одредуваат неговата функција, при што тие се претставени или како материјализирани ликови или како организациски наративни дискурси во структурата на песната. Тој е во постојан дијалог и интеракција со нив, при што тие од сите страни ја ослабуваат и ја распарчуваат сигурноста и втемеленоста во реалноста на неговиот сопствен глас. Бидејќи песната е во форма на драмски монолог, каде што за сите настани, локации, мисли и емоции сме известени преку нарацијата и гласот на главниот херој, витезот Роланд, тие стануваат дел од неговиот глас и се материјализираат во него. Тие се носители на легитимитетот и на вистината, како кодови преку кои читателот треба да го толкува светот и уметничкото дело. Меѓутоа, со нарушувањето на нивната очекувана структура и со редуцирањето на мотивите и изневерата на нивните крајни исходи во рамките на наративната структура на песната, Браунинг го проблематизира нивниот авторитет и можноста ефикасно и соодветно да ја организираат и да ја претстават реалноста. Ова тврдење е поткрепено и со фактот дека во внатрешниот монолог на Роланд, кој е испресечен во повеќе строфи (за разлика од непрекинатиот развој на мислата во другите монолози на Браунинг), постојано се менуваат различните општествени дискурси, кои го одредуваат неговиот идентитет и животен пат. Алармира отсуството на споменување на главниот фактор и мотиватор на дејствувањето на витезот, личноста или институцијата што го испратила на оваа задача. Дискурсот на романсата налага тоа да биде неговиот крал или суверен, како што е тоа случај во приказната за Светиот грал, каде што Кралот Артур е тој што ги испраќа Витезите од Тркалезната маса да го бараат Гралот. Интертекстуалната алузија кон овој мит понатаму е засилена 
со споменувањето на Дружината витези (Band), со кои заедно тргнал во авантурата, но сепак, никаде во текстот не е споменат нивниот крал. Наместо него, тој што му ја покажува насоката на почетокот на песната е сакатиот човек, кој симболички е замена за кралот и идеологијата што ја претставува тој. Сакатиот не е само физички туку е и морално деградиран, бидејќи уште во првиот стих Роланд се сомнева и го обвинува дека лаже, а дека тој ќе биде само уште една жртва на неговата злоба:

My first thought was, he lied in every word,

That hoary cripple, with malicious eye. ${ }^{3}$

(Browning 1994: 359)

Доминантно чувство што преовладува низ целиот текст е немоќта на херојот да се спротивстави на идеологиите што го контролираат и го насочуваат, така што тој послушно го следи неговиот совет и се упатува кон непознатото, иако свесен дека тоа може да го однесе во смрт. Тоа е дополнително потврдено од пејзажот низ кој минува, опишан со гротескни и морничави детали од поетот, пејзаж кој, како што рековме, го навестува безживотниот свет на Пусииа земја на Т. С. Елиот. Дури ни Природата, тој симбол на човечката преродба кај романтичарите, не може да му понуди надеж и спас:

"See

Or shut your eyes," said Nature peevishly,

"It nothing skills: I cannot help my case:

' $\mathrm{T}$ is the Last Judgment's fire must cure this place

Calcine its clods and set my prisoners free." 4

(Browning 1994: 360)

Со признанието дека не е способна ниту да понуди друга визија, ниту да ја промени реалноста, таа го делегитимира романтичарскиот дискурс и неговото тврдење дека преку книжевноста може да донесе духовна и физичка преродба. Овој дијалог се одвива во имагинацијата на Роланд, уште еден од главните романтичарски концепти, која во овој случај носи само кошмарна и безнадежна визија на светот, немоќна да му помогне да го трансцендентира моментот во кој се наоѓa. Во тврдењето дека Браунинг е фатен во костец со романтичарската визија и практика нѐ поддржува и Харолд Блум, еден од најдобрите познавачи на неговата поезија, кој тврди дека „Вииеезой Роланя йреg Мрачнайа Кула е негово соочување со влијанието на П.Б. Шели“, како и дека „песната е толку-

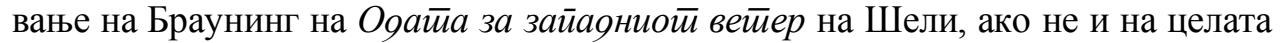
поезија на Шели“ (Bloom 2001: 56). Поетот во песната на Шели бара од западниот ветер, отелотворувањето на природата и на нејзините циклуси, да внесе нов живот и да ја разбуди неговата имагинација, да му даде инспирација за ново творештво, кое ќе му помогне да ја исполни романтичарската функција на

\footnotetext{
3 „Моја прва мисла беше дека секој збор му е лага / тоа сакато грозно човече со злобен поглед.“ (преп. на авторот)

4 „Гледај / или склопи очи,“ рече посрамено Природата,/ „Нема спас: Не можам ништо да си помогнам: / Само огнот на Судниот ден за пустошот лек ќе биде, / земјата пепел да ја стори и робјето мое да го ослободи.“(преп. на авторот)
} 
поетот како бард и пророк, кој ќе донесе преродба на културата и цивилизацијата. Немоќта на природата во песната на Браунинг само дополнително го засилува впечатокот за немоќта на романтичарската визија за улогата на поезијата во современиот свет на Браунинг.

Во монологот на Роланд свое отелотворување добиваат и гласовите на општеството и на неговото опкружување, кои ги отелотворуваат средновековните вредности на витешкиот кодекс: храброст, достоинство, чесност, жртва, лојалност, искреност и други, кои се толку натурализирани и втемелени што се втопени во гласот на мноштвото. Тие се носители на гласот на општествените норми и очекувања, кои витезот Роланд треба да ги исполни. Тоа се нормите и очекувањата што требало да ги исполнат и другите витези кои се претставници и симболи на општественото уредување и на моралниот код. Средновековниот морален код и неговите вредности се многу блиски со моралниот код и вредностите на викторијанското општество и на протестантизмот, кои се исклучително патријархални. Гласот на тој морален код, врз кој треба да се темели дејствувањето на Роланд и кој треба да служи како поткрепа во најтешките моменти, даден е во неговите сеќавања за витезите Катберт и Џајлс, чие прекршување на моралниот кодекс понатаму го делегитимира тој дискурс како успешен организациски и моделативен дискурзивен систем. Тој дискурс во текот на целата песна е дискурсот на неуспехот и апатијата што го следат Роланд во текот на целото негово патување.

Thus, I had so long suffer'd, in this quest,

Heard failure prophesied so oft, been writ

So many times among "The Band"- to wit,

The knights who to the Dark Tower's search address'd

Their steps - that just to fail as they, seem'd best.

And all the doubt was now-should I be fit?

(Browning 1994: 359)

Тој се откажува од минатото и неговите резултати и се врти кон современоста, која сѐ уште не го нашла дискурсот што ќе го осветли патот напред и ќе му помогне да му даде смисла на светот:

Better this present than a past like that;

Back therefore to my darkening path again!

(Browning 1994: 360)

Описот на светот што го опкружува Роланд е дистопичен, гротескен и кошмарен, при што тој е одраз на психолошкиот свет на ликот, но и алегорија на материјалниот свет во кој нема повеќе идеологија што може да понуди ред, организација или барем духовна утеха. Де Вејн ни открива дека поголемиот дел од сликите на тој апокалиптичен пејзаж Браунинг ги позајмил од Сийе грранки

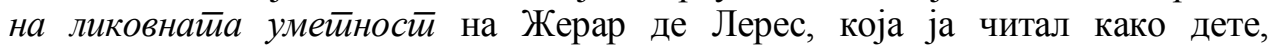

\footnotetext{
5 „Подобро ова сега отколку минатото зад мене; / Затоа, напред да го продолжам својот мрачен пат!“ (преп. на авторот)
} 
најверојатно потсвесно. Но, преку сликарскиот дискурс на симболите и сликите тој ја вклучува современоста и сите нејзини духовни и морални дилеми, надоврзувајќи се на тоа што Бахтин го нарекува сликарско претставување на различните јазици во уметноста (Bahtin 1989). Викторијанското општество на средината на XIX век се наоѓаше на пресвртница, обидувајќи се да ги задржи традиционалните форми, кои сѐ повеќе слабееја и беа делигитимирани од новите општествени околности, но во исто време, се обидуваше и да најде изразни форми преку кои ќе ги инкорпорира и ќе ги организира новите сознанија. Песната Вийезой Ролано йрея Мрачнайа Кула воедно е и дело посветено на овој обид да се најде крајното сознание и знаење. Таа на некој начин претставува еквивалент, но и антипод на еден друг драмски монолог, Ogисеј на Тенисон, кој се занимава со темата на потрагата по знаење и жедта за нови откритија. Двајцата херои се подготвени да се жртвуваат во таа мисија и се свесни за опасностите што им претстојат. Тоа што ги одделува овие две дела е песимизмот на Роланд за успехот на таа потрага, за разлика од тој на Одисеј, кој во тоа ја гледа суштината на своето херојство. Двете песни се напишани во периоди кога авторите се соочувале со креативна и духовна криза, но причината за оваа разлика може да ја најдеме во времето на нивно создавање, бидејќи Oوисеј е напишан во 1833-тата, на почетокот на викторијанскиот

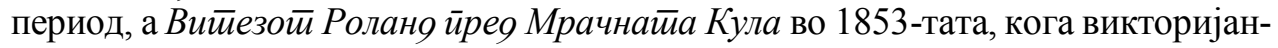
скиот период е на крајот од периодот на криза и сѐ уште не влегол во својот најстабилен и најпродуктивен период. Двете песни го одразуваат духот на времето, но ги одразуваат и карактерите на своите автори. Друга суштинска разлика од песната на Тенисон е тоа што во неа гласот и ставот на Одисеј доминираат во монологот, додека, пак, Браунинг дозволува различните општествени и книжевни јазици да го кршат и да го ослабуваат гласот на Роланд речиси до степен на признавање пораз.

\section{5 Заклучок}

Во оваа песна на Роберт Браунинг се соочуваме со поразот и со неуспехот на претходната книжевност да го најде вистинскиот одговор и дискурс за справување со предизвиците на општествената реалност. Како што ни укажува Блум, оваа песна претставува отклонување од претходниците, „визија на крај, во која сите поети од романтичарската традиција доживеале заеднички неуспех“ (Bloom 2001: 55), при што витезите што доживеале пропаст и неуспех пред Мрачната Кула ги симболизираат романтичарските поети, судбина што може да го чека и самиот Браунинг во неговото творештво и во обидот да ја перципира и да ја претстави вистината. Браунинг одговорот на оваа застрашувачка дилема ја наоѓa во недефинираниот крај на песната, која не дава еден авторитетен одговор или заокружена авторска визија. Поетот не го наоѓа одговорот во чинот на толкување, туку во чинот на дејствување. Роланд го зема рогот и наспроти крајно лошите изгледи за успех, означува дека ќе влезе во Мрачната Кула: 
And yet

Dauntless the slug-horn to my lips I set,

And blew "Childe Roland to the Dark Tower came."

(Browning 1994: 362)

Песната завршува со самиот наслов на песната, која во исто време е и цитат од Крал Лир на Шекспир, фрагмент од народна песна што ја пее Едгар престорен во лудиот Том, драма што говори за обидот да се зачуваат разумот и свеста во еден свет на предавство и пад на моралните вредности. Воедно, таа го воведува и драмскиот дискурс во семиосферата на песната, како дискурс во кој е истакнат дијалогизмот на различните јазици, но и релативизирање на хронологијата и секвенцијата на настаните, пристап што Браунинг го применува во структурата на песната. Но, тоа што е поважно е дека со наведувањето на насловот на песната Браунинг ни укажува дека неговиот одговор на предизвикот да се најде вистински јазик за опишување на светот е чинот на творењето, како и дека е подготвен да се инкорпорира во традицијата и да се обиде да го најде своето место во канонот. Отворениот и недефиниран крај е повик за читателот да го даде својот конечен суд за успешноста на неговиот потфат, но и повик преку чинот на читање и толкување на неговото дело да тргнат на истата авантура и потрага по вистината и знаењето. Неговата поезија претставува второстепен моделативен систем, во кој се репродуцира светот со сите негови спротивставени елементи и јазици, а читателот може неговото читање да го сфати како еден вид игра, преку која може да ги совлада правилата и предизвиците што владеат во тој свет. Тоа се надоврзува на идејата на Лотман дека уметноста наликува на играта, но за разлика од неа нејзината функција не е само совладување вештина туку и „совладување на светот (моделирање на светот) во условна ситуација“ (Лотман 2005: 115).

\section{Библиографија}

Bahtin. M. (1989). O romanu. Beograd: Nolit.

Bloom, H. (2001). Robert Browning Comprehensive Research and Study Guide Blooms Major Poets. New York: Chelsea House.

Bloom, H. and Fox, P. (2009). Robert Browning Blooms Classic Critical Views. New York: Chelsea House.

Browning, R. (1994). The Poems of Robert Browning. Hertfordshire: Wordsworth Editions Limited.

Byron, G. (2003). Dramatic Monologue. London: Routledge.

Kennedy, R.S. and D. S. Hair. (2007). The Dramatic Imagination of Robert Browning: A Literary Life. Columbia: University of Missoury Press.

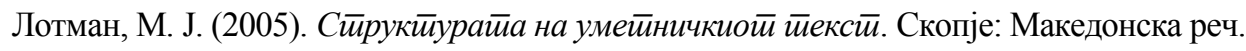

\footnotetext{
${ }_{6}^{6}$ „Сепак / непокорно до усните рогот го принесов, / и одекна 'Витезот Роланд дојде во Мрачната Кула'“. (преп. на авторот)
} 